\title{
Replication regions from plant-pathogenic Pseudomonas syringae plasmids are similar to ColE2-related replicons
}

\author{
Marjorie J. Gibbon, ${ }^{1}$ Ane Sesma, ${ }^{2}$ Arantzazu Canal, ${ }^{2}$ John R. Wood, ${ }^{1} \dagger$ \\ Elena Hidalgo, ${ }^{3}$ Judy Brown, ${ }^{1}$ Alan Vivian ${ }^{1}$ and Jesús Murillo ${ }^{2}$
}

Author for correspondence: Jesús Murillo. Tel: +34948 169133. Fax: + 34948169187. e-mail: jesus@upna.es

\footnotetext{
1 Department of Biological and Biomedical Sciences, UWE-Bristol, Coldharbour Lane, Bristol BS16 1QY, UK

2 Departamento de Producción Agraria, Universidad Pública de Navarra, 31006 Pamplona, Spain

3 Departamento de Química, Escuela Técnica Superior de Ingeniería Agraria, Avda. Alcalde Rovira Roure, 177, 25198 Lérida, Spain
}

\begin{abstract}
Many strains of the phytopathogen Pseudomonas syringae contain mutually compatible plasmids that share extensive regions of sequence homology and essential replication determinants. The replication regions of two compatible large plasmids involved in virulence or pathogenicity, PPT23A from $P$. syringae pv. tomato strain PT23 and pAV505 from P. syringae pv. phaseolicola strain HRI1302A, were isolated. DNA sequencing of the origins of replication revealed homologous ORFs, designated ORF-Pto and ORF-Pph, respectively. Both ORFs are 1311 bp long and encode peptides of 437 amino acids with predicted molecular masses of 48259 (Pto) and 48334 (Pph) Da. Expression of the two ORFs in Escherichia coli produced peptides of $50 \mathrm{kDa}$ (Pto) and $56 \mathrm{kDa}$ (Pph). The predicted peptides showed an overall identity of $89.7 \%$, being highly conserved from residues 1 to 373, but showing considerable variation in their C-terminal regions ( $50 \%$ identity over the last $64 \mathrm{aa}$ ). The two ORFs had significant similarity with the putative replication protein from plasmid pTiK12 of Thiobacillus intermedius and other ColE2-related plasmids. However, both peptides were 100 residues longer than any of the known ColE2-related rep sequences. Subcloning of fragments from the replication region of pPT23A revealed the presence of at least three incompatibility determinants, designated InCA, IncB and IncC. Partial sequencing of the region downstream of ORF-Pto revealed homology to the ruIAB genes, involved in UV resistance, from plasmid pPSR1. It is proposed that the replication origin of PPT23A serves as the prototype of a family of related plasmids.
\end{abstract}

Keywords: incompatibility, UV light resistance, Pseudomonas syringae pvs tomato and phaseolicola, virulence, pPT23A-like plasmids

\section{INTRODUCTION}

A common feature of Pseudomonas syringae strains is the presence of one or several native plasmids, ranging in size from 2 to $>200 \mathrm{~kb}$ (Curiale $\&$ Mills, 1983; Coplin, 1989; Sundin et al., 1994, Sesma et al., 1998). Whilst many of these plasmids remain cryptic, functions such as

\footnotetext{
†Present address: Scottish Agricultural Science Agency, East Craigs, Edinburgh EH12 8NJ, UK.

Abbreviations: ORF-Pph, putative replicase gene from pAV505; ORF-Pto, putative replicase gene from pPT23A.

The EMBL accession numbers for the sequences reported in this paper are AJ222648 (oriV-pAV505), AJ224509 (oriV-pPT23A, rulA), AJ224510 (partial rulAB), and $A J 006933$ (partial rulB).
}

avirulence (Vivian \& Gibbon, 1997), resistance to copper, streptomycin, or both (Cooksey, 1990; Sundin et al., 1994), and biosynthesis of extracellular virulence factors (Comai \& Kosuge, 1980; Bender et al., 1989; Nagahama et al., 1994; Kamiunten, 1995) have been identified.

$P$. syringae pv. tomato strain PT23 has four native plasmids, designated pPT23A-pPT23D and ranging in size from 36 to $100 \mathrm{~kb}$ (Bender \& Cooksey, 1986). Plasmid pPT23A (100 kb) carries the gene cluster for the synthesis of the phytotoxin coronatine (Bender et al., 1989). pPT23B ( $83 \mathrm{~kb}$ ) contains avirulence gene avrD (Kobayashi et al., 1990), which contributes to host range, and an as yet uncharacterized DNA region that putatively participates in the synthesis of a new toxin 
(Sesma et al., 1997; A. Sesma, M. T. Aizpun, A. Ortiz, D. Arnold, A. Vivian \& J. Murillo, unpublished). These two plasmids carry the main virulence determinants of strain PT23 since a strain devoid of both did not induce chlorosis, produced very small necrotic lesions and was greatly reduced in its ability to colonize tomato leaves (Bender et al., 1989; Sesma et al., 1997). Plasmid pPT23C $(65 \mathrm{~kb})$ is cryptic and pPT23D (36 kb) confers resistance to copper, a widely used bactericide. pPT23A and pPT23C were shown to be conjugative, and pPT23D could be mobilized by cointegration with pPT23C (Bender et al., 1989).

Southern hybridization experiments showed that many $P$. syringae plasmids share a large amount of DNA (Murillo \& Keen, 1994; Sesma et al., 1998), and it has been estimated that in strain PT23, $74 \%$ of plasmid pPT23B is repeated in pPT23A. Some of the repeated DNA includes putative transposable elements, replication and maintenance determinants, genes for UV resistance (Murillo \& Keen, 1994; Sesma et al., 1998) and genes involved in conjugation (A. Canal, A. Sesma $\& \mathrm{~J}$. Murillo, unpublished). The replication region of plasmid pPT23A was identified by hybridization with a $1.2 \mathrm{~kb}$ HindIII fragment containing an uncharacterized origin of replication from the $P$. syringae pv. syringae plasmid pOSU900 (Mukhopadhyay et al., 1990; Murillo \& Keen, 1994). The defined minimal replication region of pPT23A hybridized to the co-resident plasmids pPT23B and pPT23D in strain PT23 and to six different plasmids that were co-resident in a strain of $P$. syringae pv. glycinea (Murillo \& Keen, 1994; Sesma et al., 1998). This region was shown to be highly conserved among plasmids in $P$. syringae pathovars. These results suggest that most of the plasmids in $P$. syringae may be derived from a common ancestor through accumulation of mutations that permit the observed compatibility of highly related plasmids.

P. syringae pv. phaseolicola race 4 strain HRI1302A has four native plasmids, designated pAV505 $(150 \mathrm{~kb})$, pAV506 (50 kb), pAV507 (47 kb) and pAV508 (42 kb) (Jackson, 1997). Plasmid pAV505 is essential for the production of disease on bean plants and other hosts (Jackson, 1997). Additionally, an avirulence phenotype, which matched a resistance gene in pea (Pisum sativum), was shown to require the presence of two cloned regions of DNA, designated regions I and II. The two regions were separated by approximately $4 \mathrm{~kb}$ and located on pAV505 (Wood et al., 1994). The cloned region II displayed a strong incompatibility with pAV505 (Jackson, 1997) and hybridized with the minimal replication region of pPT23A. This suggested that it could be part of the pAV505 replication region and that it could participate in avirulence (M. J. Gibbon, D. L. Arnold \& A. Vivian, unpublished).

In this work we characterize the replication regions of these two plasmids with the aim of gaining a better understanding of the determinants and mechanisms that allow for the coexistence of highly related replicons in $P$. syringae, and thus for the horizontal distribution of pathogenicity determinants.

\section{METHODS}

Bacterial culture conditions. Strains and plasmids used in this work are listed in Table 1 and Fig. 5. Escherichia coli was grown on Luria-Bertani (LB) medium (Sambrook et al., 1989) at $37^{\circ} \mathrm{C}$, and P. syringae on King's medium $\mathrm{B}$ (KMB) (King et al., 1954) or LB at $25-28^{\circ} \mathrm{C}$. When necessary, media were supplemented with antibiotics at the following concentrations $\left(\mu \mathrm{g} \mathrm{ml}^{-1}\right)$ : ampicillin, 100; kanamycin, 25; tetracycline, $12 \cdot 5$.

Genetic manipulations. Standard molecular biology techniques were performed as described by Sambrook et al. (1989). Plasmids were isolated by a modified alkaline lysis procedure (Zhou et al., 1990) and intact native plasmids were separated by electrophoresis on $0.6 \%$ agarose gels in $1 \times$ TAE as previously described (Murillo et al., 1994). DNA fragments separated in low-melting-point agarose (Life Science, GibcoBRL) were ligated as described by Crouse et al. (1983). DNA was introduced into $P$. syringae cells by triparental conjugation or electroporation (Keen et al., 1992).

Double-stranded DNA, purified by extraction on mini columns (Qiagen), was sequenced by PCR using the AmpliCycle kit (Perkin-Elmer), following the manufacturer's recommendations. Primers for sequencing were pUC M40 forward and reverse, and custom-synthesized oligonucleotides (15 to 20 -mer) based on previously determined sequences within individual inserts. Clones for sequencing were either previously obtained by exonuclease III digestion of appropriate plasmids (Murillo \& Keen, 1994) or by subcloning of specific restriction fragments in pBluescript or pK184. The sequence was analysed using the University of Wisconsin GCG package, available through the SEQNET facility at Daresbury, UK (Devereux et al., 1984). Homology searches were performed using the BLAST network service at the NCBI, Bethesda, MD, USA, and FASTA at Daresbury, and alignments were done using CLUSTAL $w$ at the EBI, Cambridge, UK, or the IBCP, Lyon, France. Phylogenetic trees were constructed using the neighbour-joining method at the CLUSTAL w server at the EBI, and viewed using TREEVIEw software (Page, 1996).

Plasmid pAori60 was subjected to mutagenesis with Tn3HoKmGus (Bonas et al., 1989) as described by Dangl et al. (1992). Expression of the Tn3Gus fusions was analysed using 4-methylumbelliferyl- $\beta$-D-glucuronide (Biosynth) following published methodology (Gallagher, 1992). The precise location of selected insertions was determined by sequencing using specific primers for the terminal repeats of the transposon. To determine the effect of individual transposon insertions on the replication ability of oriV-pPT23A, inserts of selected clones were excised from the vector by digestion with $K p n I$, which does not cut inside the transposon, and cloned in $\mathrm{pK} 184$. The replication ability of the resulting clones was then assessed by their capacity to transform the plasmidless strain P. syringae pv. syringae FF5.

In vivo expression and labelling of proteins in $E$. coli. Highlevel expression of appropriate constructs was performed with a T7 RNA polymerase-promoter system using E. coli BL21(DE3), and proteins were specifically labelled with $\mathrm{L}$ $\left[{ }^{35} \mathrm{~S}\right]$ methionine (Amersham) essentially as described by Studier \& Moffatt (1986) and Hidalgo et al. (1992). The labelled proteins were resolved by electrophoresis in $12 \%$ SDS-polyacrylamide gels and analysed by autoradiography (Sambrook et al., 1989).

Incompatibility assays. The identification of determinants in pAKC showing incompatibility against the parent plasmid PPT23A was assayed by a qualitative test essentially as 
Table 1. Bacterial strains and plasmids

\begin{tabular}{|c|c|c|}
\hline Strain or plasmid & Relevant characteristics & Reference or source \\
\hline \multicolumn{3}{|l|}{ Strains } \\
\hline \multicolumn{3}{|l|}{ Escherichia coli } \\
\hline BL21(DE3) & bsdS gal ( $\lambda$ cIts857 ind1 Sam7 nin5 lacUV5-T7 gene 1) & Studier \& Moffatt (1986) \\
\hline $\mathrm{DH} 5 \alpha$ & $\begin{array}{l}\left.\mathrm{F}^{-} \text {slacU169 ( } \phi 80 \text { lacZ } \Delta \mathrm{M} 15\right) \text { endA1 recA1 hsdR17 } \\
\text { supE44 thi-1 gyrA96 relA1 }\end{array}$ & $\begin{array}{l}\text { Bethesda Research Laboratory, } \\
\text { Gaithersburg, MD, USA }\end{array}$ \\
\hline \multicolumn{3}{|l|}{ Pseudomonas syringae } \\
\hline pv. phaseolicola HRI1302A & $\begin{array}{l}\text { Contains four plasmids: pAV505 (150 kb), pAV506 } \\
(50 \mathrm{~kb}) \text {, pAV507 }(47 \mathrm{~kb}) \text { and pAV508 }(42 \mathrm{~kb})\end{array}$ & Jackson (1997) \\
\hline pv. syringae FF5 & Plasmidless & Sundin \& Bender (1993) \\
\hline pv. tomato РT23 & $\begin{array}{l}\text { Contains four plasmids: pPT23A }(100 \mathrm{~kb}) \text {, pPT23B } \\
(83 \mathrm{~kb}), \text { pPT23C }(65 \mathrm{~kb}) \text { and pPT23D }(36 \mathrm{~kb})\end{array}$ & Bender \& Cooksey (1986) \\
\hline \multicolumn{3}{|l|}{ Plasmids } \\
\hline pAKC & $\begin{array}{l}9 \cdot 2 \mathrm{~kb} K p n \mathrm{I} \text { fragment containing the minimal region } \\
\text { necessary for replication from pPT } 23 \mathrm{~A} \text { cloned in } \mathrm{pK} 184\end{array}$ & Murillo \& Keen (1994) \\
\hline pAori1 & $\begin{array}{l}2.4 \mathrm{~kb} \text { partial EcoRI fragment from pAKC cloned in } \\
\text { pK184; contains the minimal replication region from } \\
\text { pPT23A }\end{array}$ & Murillo \& Keen (1994) \\
\hline pAori2 & $\begin{array}{l}\text { As pAori1, but with an additional } 0 \cdot 2 \mathrm{~kb} \text { EcoRI fragment, } \\
\text { and opposite orientation; ORF-Pto is transcribed from } \\
\text { the lac promoter }\end{array}$ & Murillo \& Keen (1994) \\
\hline pAori23 & $\begin{array}{l}\text { Obtained by religation of pAori } 2 \text { digested with } P s t \mathrm{I} \text {, } \\
\text { blunted and digested with Eco R V; contains an } 1.5 \mathrm{~kb} \\
\text { EcoRI (partial)-EcoRV fragment that can replicate in } P \text {. } \\
\text { syringae; ORF-Pto is truncated by } 67 \mathrm{nt}\end{array}$ & This work \\
\hline pAori41 & $\begin{array}{l}2 \mathrm{~kb} \mathrm{BglII-EcoRV} \text { from pAori1 cloned in BamHI-EcoRV } \\
\text { of pBluescript; ORF-Pto is truncated by } 67 \mathrm{nt} \text { and is } \\
\text { under the control of the T7 promoter of the vector }\end{array}$ & This work \\
\hline pAori42 & As pAori41, but opposite orientation & This work \\
\hline pAori44 & $\begin{array}{l}9.2 \mathrm{~kb} K p n \mathrm{I} \text { fragment from } \mathrm{pAKC} \text { joined to the } \mathrm{Sm}^{\mathrm{r}} \\
\text { cassette from } \mathrm{pSmUC}\end{array}$ & This work \\
\hline pAori60 & $9 \cdot 2 \mathrm{~kb} K p n \mathrm{I}$ fragment from pAKC cloned in $\mathrm{pRK} 415$ & This work \\
\hline pAV514 & $\begin{array}{l}4 \cdot 3 \mathrm{~kb} \text { Pst I fragment from pPPY } 40 \text { cloned in } \mathrm{pK} 184 \text {; } \\
\text { orientation of ORF-Pph in opposition to the vector lac } \\
\text { promoter }\end{array}$ & This work \\
\hline pAV515 & As pAV514, but opposite orientation & This work \\
\hline $\begin{array}{l}\text { pBluescript } \mathrm{KS}(+) \\
\text { pBluescript } \mathrm{SK}(-)\end{array}$ & $\mathrm{Ap}^{\mathrm{r}}$, E. coli cloning vectors containing $\mathrm{T} 7$ promoter & Stratagene, La Jolla, CA, USA \\
\hline pHoKmGus & $\begin{array}{l}\mathrm{Ap}^{\mathrm{r}} \mathrm{Km}^{\mathrm{r}} \text { tnpA, } \mathrm{pWB} 15 \mathrm{a} \text { replicon, promoter-less } \beta \text { - } \\
\text { glucuronidase gene in } \operatorname{Tn} 3\end{array}$ & Bonas et al. (1989) \\
\hline pSShe & $\mathrm{Cm}^{\mathrm{r}} \operatorname{tn} p A^{+}, \mathrm{pACYC} 184$ replicon & Stachel et al. (1985) \\
\hline pK184 & $\mathrm{Km}^{\mathrm{r}}$, E. coli cloning vector, p15a replicon & Jobling \& Holmes (1990) \\
\hline pPPY 40 & $\begin{array}{l}\mathrm{Tc}^{\mathrm{r}} \text {, pLAFR3-based cosmid containing a } 25 \mathrm{~kb} \text { fragment } \\
\text { from pAV505, }\end{array}$ & Wood et al. (1994) \\
\hline pPPY 50 & $\begin{array}{l}4.3 \mathrm{~kb} \text { Pst I fragment from pPPY } 40 \text { cloned in pBluescript } \\
\mathrm{KS}(+) \text {; ORF-Pph under the control of the T7 promoter } \\
\text { of the vector }\end{array}$ & This work \\
\hline pPPY51 & As pPPY50, but opposite orientation & This work \\
\hline pRK415 & $\mathrm{Tc}^{\mathrm{r}}$, broad-host-range cloning vector, IncP replicon & Keen et al. (1988) \\
\hline pSmUC & $\begin{array}{l}A p^{r} S m^{r} S p^{r} \text {, contains a } S m / S p \text { cassette symmetrically } \\
\text { flanked by diverse restriction sites }\end{array}$ & Murillo et al. (1994) \\
\hline
\end{tabular}

described by Nordström (1993). Clones constructed in pK184 (pAori23 and pAori25) or pRK415 were introduced into PT23 by electroporation. Resulting transformants were selected on
$\mathrm{KMB}$ plus the appropriate antibiotic and, after three sequential single colony purifications on the same medium, the plasmid profiles were analysed. At least two transformants 
from at least three separate electroporation experiments were analysed for each clone.

\section{RESULTS}

\section{The minimal origins of replication encode a putative replication protein}

The origin of replication from plasmid pPT23A, from $P$. syringae pv. tomato PT23 was cloned as a $9 \cdot 2 \mathrm{~kb} K p n \mathrm{I}$ fragment in pK184, which does not replicate in $P$. syringae, to give pAKC (Murillo \& Keen, 1994). Using exonuclease III deletion clones in an in vivo replication assay, the minimal fragment from pAKC able to support replication in P. syringae (oriV-pPT23A) was defined as a $1.6 \mathrm{~kb}$ fragment. The nucleotide sequence of this fragment (1662 nt) contains a large ORF (ORF-Pto; Fig. 1a) that could encode a polypeptide of 437 aa, with a predicted molecular mass of $48259 \mathrm{Da}$. Further experiments reduced the minimal fragment which retained the capacity for replication in $P$. syringae to a $1556 \mathrm{bp}$ EcoRI (partial)-EcoRV fragment (designated pAori23; Fig. 1a and data not shown), which contained ORF-Pto, Cterminally truncated by 21 aa.

A $4.3 \mathrm{~kb}$ Pst I fragment from P. syringae pv. phaseolicola HRI1302A cosmid clone pPPY40, involved in an avirulence phenotype (Wood et al., 1994), was found by hybridization to be similar to oriV-pPT23A (data not shown). Plasmids pAV514 and pAV515, which contain the $4.3 \mathrm{~kb}$ PstI fragment from pPPY40 in pK184 in different orientations, replicated autonomously in strain PT23 and were compatible with plasmid pPT23A, even after four transfers in media with kanamycin. The nucleotide sequence of a $1675 \mathrm{bp}$ fragment internal to the $4.3 \mathrm{~kb}$ Pst I fragment (Fig. 1a) showed a high overall

(a)
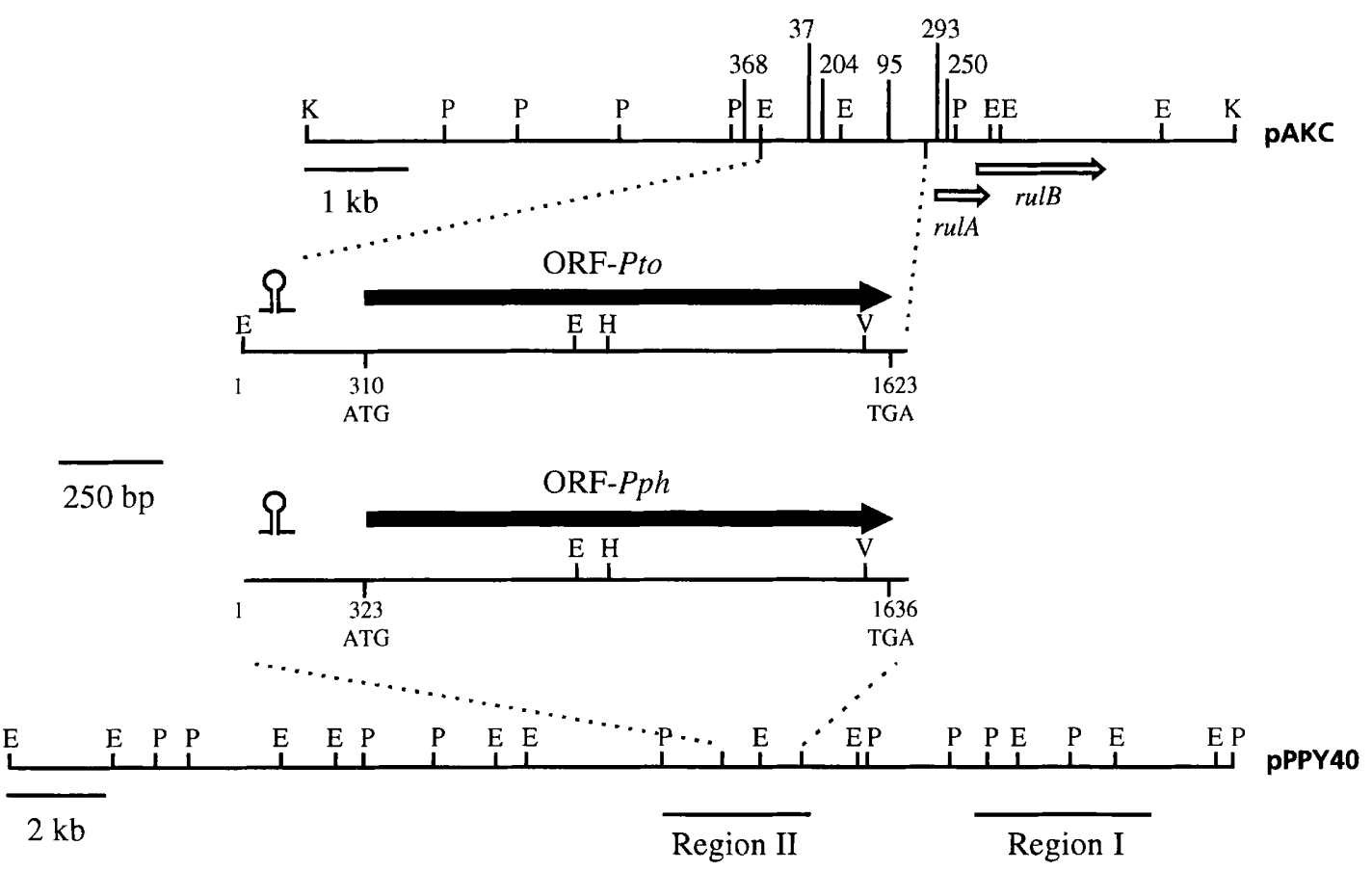

(b)

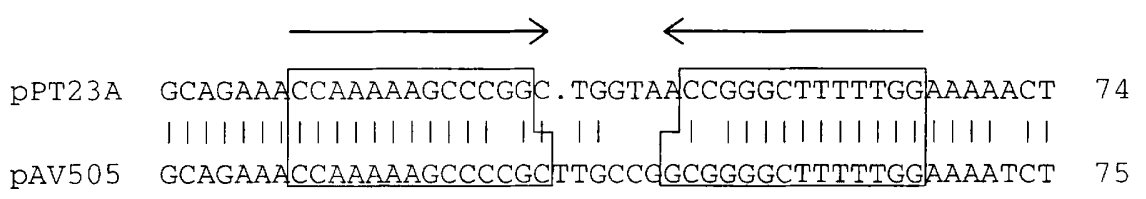

Fig. 1. (a) Genetic organization of the replication regions of $\mathrm{pAKC}$, derived from $\mathrm{pPT} 23 \mathrm{~A}$, and pPPY40, derived from pAV505. The enlargements show the sequenced fragments, and the position and orientation of the putative replicase genes (ORF-Pto and ORF-Pph) are indicated by arrows. The loops represent major repeats found upstream of both ORFs. Selected Tn3HoKmGus insertions in pPT23A DNA are shown by vertical lines with the corresponding insertion number. The position and orientation of the partially sequenced rulAB homologue are indicated. The length of rul $A B$ was proportionately extended beyond the sequenced DNA based on the homology with the rulAB genes from pPSR1. E, ECoRI; H, HindIII; K, KpnI; P, Pstl; V, EcoRV. (b) The major repeated sequence found upstream of the putative replicases. Boxes indicate nucleotides that could be pairing to form a stem-and-loop structure. 
PPT23A MSHDNAISLA LATSSTANAD PN TISTHFPP ARFFEBGTAL NRLLLEAPYM pAV505 MSHDNAISLA LATSPTANAD PUATSTHUJPP ARFFEDGTAL NRLLLEAPYL,

PPT23A SFLKOGFSEN LPLSSIRATV KSVGRWTWDR YTGDRRCHRG AMQLDSSLSL PAV505 SFLKQGFSEN LPLSSIRATV KSVGRWTWDR YTGDRRCHRG AMQLDGSLSL

PPT23A TERQSLAAKR TNELRHKATE SKIRAACRQL QDQGKTLVRS AIATLAGISV PAV505 TERQSLAAKR TNELRHKATE SKIRAACRQL QDQGKALVRS AIATLAGUSV

PPT23A RTVASYTHIL TEVSQPSTVS VLRGTRQPAK AATGAHGQVD STTPOFAFGQ 400 $\begin{array}{lll}\text { PAV505 RTVASYAHIL TEVSRPATVS VLRASRKAVS VPPRQDRSPA TPPVDAHVGQ } & 400\end{array}$ PPT23A AANRRAPGVQ SGVHOISAGP RGPQAGEPLK KEHDDCS PAV505 PADGRASSVQ SGVHQISAVP QGPQAGELLK TEHDDCS
Fig. 2. Comparison of the putative Rep proteins from PPT23A and pAV505. Non-conservative substitutions are in white lettering on a black background and conservative substitutions are boxed. For simplicity, the sequence from position 51 to 250 , where only a conservative substitution was found at position 180 , has been omitted. The filled arrowhead indicates the start of the deletion on pAori23.

similarity $(88.8 \%$ identity in the putative coding regions, and $84.4 \%$ identity in the preceding DNA) to the sequence of oriV-pPT23A and was designated oriVpAV505. A large ORF, ORF-Pph, was present in oriVpAV505 between nt 323 and 1636 . ORF-Pph is predicted to encode a polypeptide of $437 \mathrm{aa}$, with a predicted molecular mass of $48334 \mathrm{Da}$.

The polypeptides deduced from ORF-Pto and ORF-P $p h$ showed an overall identity of $89.7 \%$ and were almost identical from position 1 to 373 (96.5\% identity) (Fig. 2). The sequences, however, were different from position 374 to 437 ( $50 \%$ identity), with changes concentrated in a region of 35 residues (positions 374-408) where only seven identical residues could be found. The overall $\mathrm{G}+\mathrm{C}$ content of oriV-pPT23A and oriV-pAV505 was 58.2 and $59.1 \mathrm{~mol} \%$, respectively, which is at the lower limit of the mean content of the $P$. syringae chromosome (Palleroni, 1984).

Approximately $250 \mathrm{bp}$ upstream of the putative ATGs of both ORF-Pto and ORF-P $p h$ there is a perfect inverted repeat with a 13 or 14 bp stem, respectively, and a 7 or 6 bp loop, respectively, surrounded by short (3-5 nt) poly (A) stretches (Fig. 1b). The change of a $G$ in the left branch of the stem in oriV-pPT23A for a $\mathrm{C}$ in oriVpAV505 is accompanied by a corresponding complementary change in the right arm, so that the stem in oriV-pAV505 still forms a perfect repeat. Additional inverted or direct repeats, of nine or more nucleotides, conserved in both sequences, were not found, nor did we detect features common to origins of replication containing iterons, which are present, for instance, in the origins of plasmids pPS10 from $P$. syringae pv. savastanoi (Nieto et al., 1992) and pRO1600 from Pseudomonas aeruginosa (West et al., 1994).

The sequence of three non-contiguous fragments (totalling $728 \mathrm{nt}$ ) downstream of ori $V$-pPT23A (Fig. 1a), showed a high degree of similarity to the $r u l A B$ genes of plasmid pPSR1 of $P$. syringae pv. syringae A2 (Sundin et al., 1996). A 16 bp sequence, highly homologous to the

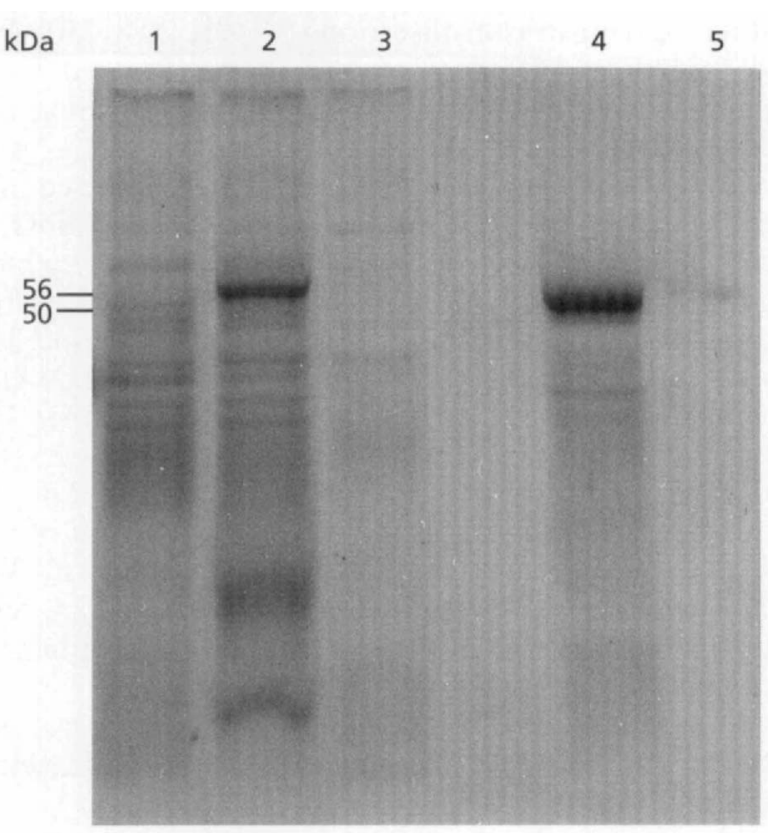

Fig. 3. Analysis of polypeptides produced from ORF-Pto and ORF-Pph. Autoradiogram of $\left[{ }^{35} \mathrm{~S}\right]$ methionine-labelled polypeptides separated by SDS-PAGE from cell extracts of $E$. coli BL21(DE3) bearing pPPY51 (lane 1), pPPY50 (lane 2), pBluescript $\mathrm{KS}(+)$ (lane 3), pAori41 (lane 4) and pAori42 (lane 5). Numbers on the left indicate the size of the specifically labelled products.

consensus binding site for LexA and located -45 to -30 relative to the start codon of rulA in pPSR1, was conserved in sequence and position in pPT23A. The putative start codons of $r u l A$ and $r u l B$, and the stop codon of rulA, were also conserved in pPT23A.

\section{ORF-Pto and ORF-Pph produce proteins of the expected size}

Plasmids pAori41, pAori42, pPPY50 and pPPY51 were introduced into $E$. coli $\mathrm{BL} 21(\mathrm{DE} 3)$. Appropriate cultures induced with IPTG were pulse-labelled with $\left[{ }^{35} \mathrm{~S}\right]$ methionine for $5 \mathrm{~min}$, and total cell lysates were separated by SDS-PAGE (Fig. 3). Plasmids pAori41 and pPPY50, in which ORF-Pto and ORF-Pph were under the control of the T7 promoter, directed the specific labelling of approximately 50 and $56 \mathrm{kDa}$ polypeptides, respectively. The direction of transcription of the genes and the sizes of the products, as deduced from the sequences (both $48.3 \mathrm{kDa}$ ), correlate with these results, since although the insert in pAori41 [fragment $1.5 \mathrm{~kb}$ EcoRI (partial)-EcoRV] lacks the last 21 residues of ORF-Pto, the construction adds 19 residues from the vector sequences to the ORF. We cannot account for the difference in size between the deduced product of ORF$P p h$ and the expressed product in E. coli.

\section{Transposon mutants in ORF-Pto do not replicate}

Plasmid pAori60, which contains a $9 \cdot 2 \mathrm{~kb} K p n \mathrm{I}$ fragment including oriV-pPT23A in pRK415, was subjected to mutagenesis with Tn3HoKmGus. The KpnI fragments 
containing transposon insertions 37, 95, 204, 250, 293 and 368 (Fig. 1a) were cloned in pK184 and their capacity to replicate was assayed by transforming the individual clones in $P$. syringae pv. syringae FF5. Clones carrying insertions 37, 95 and 204, located in the coding region of ORF-Pto, did not yield any transformants in three separate electroporation experiments, which suggests that they inactivate a function essential for replication. Clones carrying insertions 250, 293 and 368 consistently yielded $10^{3}-10^{5}$ transformants $\left(\mu \mathrm{g}\right.$ DNA) ${ }^{-1}$ when introduced into strain FF5. Insertion number 368 is located in IncA, $603 \mathrm{bp}$ upstream of the putative start codon of ORF-Pto, whilst insertions 293 and 250 are located 56 and $143 \mathrm{bp}$, respectively, downstream of the putative stop codon of this ORF (data not shown). We did not detect $\beta$-glucuronidase activity in PT23 cells carrying any of the transposon insertions, either in exponential or stationary phases.

\section{ORF-Pto and ORF-Pph are similar to other replication proteins}

Searches of the databases revealed that the nucleotide sequences of ORF-Pto and ORF-Pph showed a high similarity $(52.8 \%$ overall identity) with the coding region of the putative replication protein of plasmid pTiK12 $(65 \mathrm{~kb})$ from Thiobacillus intermedius K12 (English et al., 1995). The polypeptides deduced from ORF-Pto and ORF-Pph (Fig. 2) showed a $45.9 \%$ overall identity with the putative replication protein of pTiK12 and a significant similarity with the replication proteins of the ColE2-related plasmids and several other plasmids from Gram-negative and Gram-positive bacteria, as well as with the PspPI DNA methyltransferase, associated with the PspPI restriction-modification system, from Psychrobacter sp. (Rina et al., 1997) (Fig. 4 and data not shown). The degree of homology among all these proteins is higher in the first two-thirds of the sequence, and they are poorly conserved in the Cterminal part, both in sequence and in length. The proteins deduced from ORF-Pto and ORF-P $p h$ were more than 100 residues larger than any of the proteins in this group. Two putative adjacent ORFs of the streptomycin-resistance plasmid pCPP519 from Pseudomonas sp. PyR19 (T. C. Huang \& T. J. Bur, EMBL accession no. AF029751) also showed a high similarity to the first (71\% identity over $138 \mathrm{aa}$ ) and second $(53 \%$ identity over $131 \mathrm{aa}$ ) half of ORF-Pto (Fig. 4 and data not shown). This could imply either a mutational event or a sequencing error, leading to the apparent frameshift in the pCPP519 sequence.

Given the similarity to the ColE2-related replicons, we were interested to see whether the pPT23A-like replicons were maintained in E. coli. However, we consistently failed to obtain transformants of $E$. coli $\mathrm{DH} 5 \alpha$ using pAori44, which contains the $9 \cdot 2 \mathrm{KpnI}$ fragment from pAKC joined to a $\mathrm{Sm} / \mathrm{Sp}$ cassette, either at 28 or $37^{\circ} \mathrm{C}$. This result suggests that the similarity among ORF-Pto and the replicases from the ColE2-related plasmids is not sufficient to allow the replication of oriV-pPT23A in E. coli.

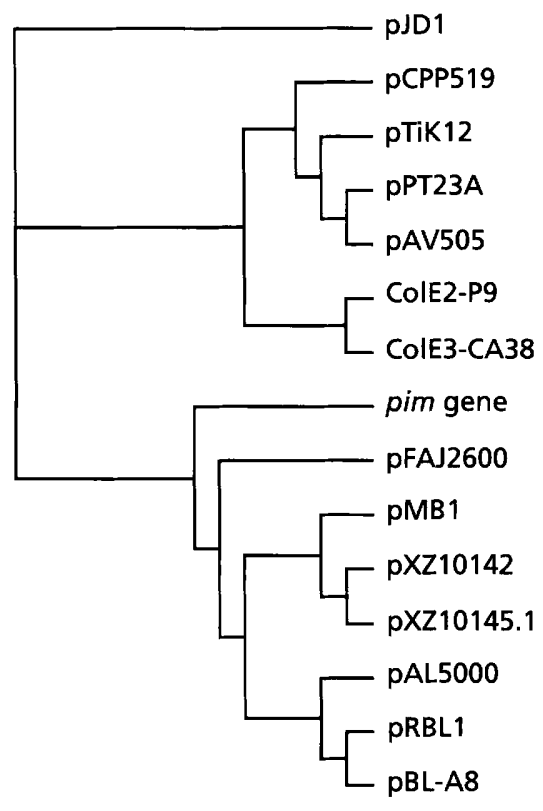

Fig. 4. Dendrogram of genetic relatedness of (putative) replication proteins and a methyltransferase. The tree was constructed by the neighbour-joining method using the CLUSTAL w Multiple Sequence Alignment interactive program available at the EBI, Cambridge, UK, and displayed using TREEVIEW. Replication proteins are from the following plasmids: pMB1 from Bifidobacterium longum (Rossi et al., 1996); pXZ10142 (S. L. Shi, Z.X. Wang, Y. Deng, H. Zhu, B. He, \& Z. X. Zheng, EMBL accession no. X72691) and pXZ10145.1 (Z. Zheng, S. Shi, X. Jiang, Z. Wang \& L. Caro, accession no. U85507) from Corynebacterium glutamicum; pFAJ2600 from Rhodococcus erythropolis (De Mot et al., 1997); pJD1 from Neisseria gonorrhoeae (Korch et al., 1985); pTiK12 from Thiobacillus intermedius K12 (English et al., 1995); PPT23A, deduced from ORF-Pto, from $P$. syringae pv. tomato PT23; pAV505, deduced from ORF-Pph, from $P$. syringae pv. phaseolicola HRI1302A; ColE2-P9 from Shigella sp. and ColE3-CA38 from E. coli (Hiraga et al., 1994); pAL5000 from Mycobacterium fortuitum (Rauzier et al., 1988); pRBL1 (Ankri et al., 1996) and pBL-A8 (V. Leret, accession no. Y11902) from Brevibacterium linens. pCPP519 denotes the sequence of ORF2, which could encode a 157 aa protein of unknown function, from the streptomycin resistance plasmid pCPP519 from the non-fluorescent Pseudomonas sp. PyR19 (T. C. Huang \& T. J. Burr, accession no. AF029751; see text), and pim is the gene for a methyltransferase from Psychrobacter sp. (Rina et al., 1997). For simplicity, other plasmids of the ColE2-family were not included in the tree.

\section{Identification of two putative maintenance determinants in the PPT23A replication region}

Low-copy-number bacterial plasmids are generally stably maintained because they encode several systems that minimize plasmid loss during cell division. As a result of their activity, the majority of these maintenance systems express incompatibility toward their parent plasmids (Novick, 1987; Austin \& Nordström, 1990; Nordström, 1993). Taking advantage of this, we sought to identify other replication or maintenance determinants in pAKC by testing the ability of different restriction fragments from it to evict pPT23A by incompatibility. 


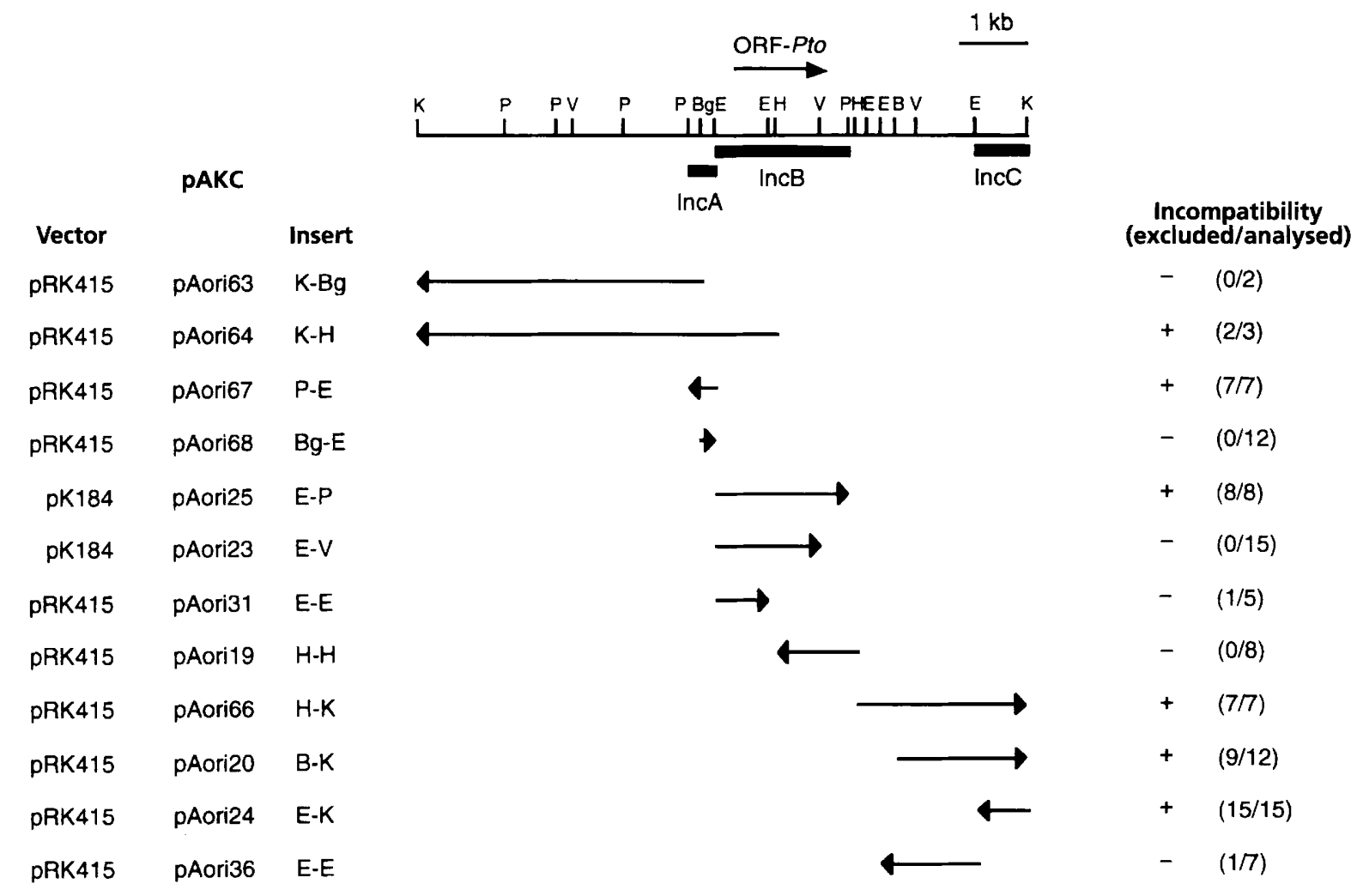

Fig. 5. Mapping of incompatibility regions in pAKC. Restriction fragments listed in the third column and represented by horizontal arrows were cloned in pK184 or in pRK415, as indicated, and introduced by electroporation into strain PT23. After three successive single colony purifications on KMB plus kanamycin for pK184, or KMB plus tetracycline for pRK415, the plasmid profile of transformants was analysed. Incompatibility with pPT23A was scored as + or - if at least half or less than half, respectively, of the transformants analysed had lost PPT23A, as determined by gel electrophoresis. The number of transformants that lost PPT23A and the total number analysed are shown in parentheses. Arrows indicate the direction of transcription from the lac promoter in the vector. Transformants came from at least three different electroporations. B, BamHI; Bg, Bg/ll; E, EcoRI; H, HindIII; K, Kpnl; P, Pstl; V, EcoRV.

Restriction fragments from pAKC, cloned in $\mathrm{pRK} 415$ or pK184, were introduced individually into strain PT23 by electroporation and the plasmid profile of the resulting transformants was analysed to check for the loss of pPT23A. The results (Fig. 5) indicate that at least three separable incompatibility determinants are included in pAKC, which, due to the incompatibility phenotype, could contain replication or maintenance determinants. The first of them was specified on the $0.4 \mathrm{~kb}$ Pst I-EcoRI fragment located immediately upstream of oriVpPT23A and has been designated IncA. The second determinant (IncB) was contained in a $2 \mathrm{~kb}$ EcoRI-Pst I fragment that spans the minimal fragment with capacity to replicate. In ColE2-related plasmids, the incompatibility displayed by the minimal replicating fragment was due to either the origin of replication, a sequence of around $30 \mathrm{bp}$, or to a small regulatory antisense RNA (Hiraga et al., 1994). In this case, we were unable to locate IncB more precisely since pAori31 only showed a partial incompatibility, whilst pAori19 did not lead to the curing of pPT23A in any of the eight transformants analysed. Moreover, pAori23, which contains the first $1556 \mathrm{bp}$ of oriV-pPT23A and could replicate autonomously in $P$. syringae, did not displace pPT23A in 15 transformants analysed, although in most of them both pPT23A and pPT23B showed alterations in size after five consecutive transfers under kanamycin selection on KMB (data not shown). The third determinant, designated IncC, comprised the $0.8 \mathrm{~kb} E c o \mathrm{RI}-K p n \mathrm{I}$ fragment of pAKC, which showed a strong incompatibility against pPT23A.

\section{DISCUSSION}

In P. syringae strains, it is common to find one or several plasmids cross-hybridizing to an uncharacterized origin of replication from the $P$. syringae pv. syringae plasmid pOSU900 (Mukhopadhyay et al., 1990; Murillo \& Keen, 1994; Sundin et al., 1994). The origin of replication of plasmid pPT23A is now the best-characterized member of this family of plasmids, and in consequence we propose to designate it the pPT23A-like family. pPT23A and pAV505 are compatible pPT23A-like plasmids from $P$. syringae $\mathrm{pv}$. tomato $\mathrm{PT} 23$ and $P$. syringae $\mathrm{pv}$. phaseolicola HRI1302A, respectively. Both plasmids are important or essential for the interaction of these bacteria with their host plants since they carry virulence 
and/or pathogenicity determinants (Bender et al., 1987; Jackson, 1997; Sesma et al., 1997) and are stably maintained in spite of coexisting with other similar replicons in the same cell. The results presented here provide a preliminary characterization of the closely related replication regions of these two plasmids from different pathovars of $P$. syringae.

The minimal regions required for replication of pPT23A and pAV505 are contained on approximately $1.6 \mathrm{~kb}$ DNA fragments. The most prominent features of the nucleotide sequences of these fragments are a repeated sequence that could form a stem-and-loop structure and a large ORF (1311 nt), which are separated by around $250 \mathrm{nt}$ (Fig. 1). Although the role of the repeated sequence is currently unknown, it is possible that it plays an important role in replication since it is well-conserved in the two replication regions, and similar putative stemand-loop structures are essential elements of many other replicons (del Solar et al., 1998). The nucleotide sequences of the putative ORFs (ORF-Pto and ORF$P p h)$ are very similar to the sequence of the corresponding replication protein of plasmid pTiK12 from $T$. intermedius. We do not currently have a satisfactory explanation for this fact, since although it could suggest the horizontal exchange of replicons between the two genera, $T$. intermedius is a chemolithotroph that does not colonize the same niches as $P$. syringae (Holt et al., 1994). Also, the deduced polypeptides of the two ORFs are highly similar to the replication proteins (RepA) found in the origins of replication of other plasmids (Figs 2, 4). The synthesis of polypeptides of the expected size from these regions in an in vivo system, abolition of the replication phenotype by transposon insertions on the putative RepA coding region from pPT23A, and the high homology of the deduced polypeptides with characterized RepA proteins from other plasmids further support the idea that ORF-Pto and ORF-Pph indeed encode replication proteins. It is interesting to note that these two putative RepA proteins are more than 100 aa larger than any other homologous RepA.

The proteins deduced from ORF-Pto and ORF-P $p h$ are nearly identical from residues 1 to 373 in their $\mathrm{N}$ terminal ends (96.5\% identity), but are different from positions 374 to 437 in their C-termini (50\% identity) (Fig. 2). The lower conservation of the C-terminal part of the putative RepA proteins also seems to occur among other pPT23A-like plasmids, since a DNA probe corresponding to the $3^{\prime}$ half of ORF-Pto did not hybridize to all the plasmids that showed hybridization to the rest of oriV-pPT23A (Murillo \& Keen, 1994). These differences in the C-terminal parts of the putative RepA proteins suggest that this end might be involved in specific recognition of the origin. Furthermore, a plasmid clone containing oriV-pPT23A with a modified ORF-Pto lacking the wild-type DNA for the last 21 residues (pAori23) is still able to replicate, but shows an altered incompatibility phenotype (Fig. 5). It has been suggested that the $\mathrm{C}$-terminal regions in RepA proteins of the ColE2-related plasmids, which are highly related to the pPT23A-family (Fig. 4), play an important role in their interaction with the origin and, thus, in incompatibility (Hiraga et al., 1994).

pAKC contains at least three regions, designated IncA, IncB and IncC, that show a strong incompatibility with pPT23A (Fig. 5). In general, the determinants that express strong incompatibility are those involved in replication, partition, determination of copy number and stabilization through killing (Novick, 1987; Austin \& Nordström, 1990; Nordström, 1993). As expected, the replication region corresponded to one of the identified Inc determinants, IncB. Although we were unable to further define the location of the determinant inside the minimal region required for replication, it is likely to lie at its $3^{\prime}$ end since pAori23 showed an altered incompatibility phenotype (Fig. 5). The size of IncA $(0.4 \mathrm{~kb})$ and its position in the immediate vicinity of the minimal replicating region (Nordström, 1993) suggests that it could be involved in copy number control. Partition systems usually consist of two loci and a cisacting partition site, which generally acts as a strong incompatibility determinant (Nordström \& Austin, 1989). IncC was shown to be included in a $0.8 \mathrm{~kb}$ $E c o$ RI-KpnI fragment. Taking into account its size and that pAKC is rapidly lost upon subculturing in nonselective media (Murillo \& Keen, 1994), it is possible that the defined IncC includes a cis-acting partition site and that pAKC does not contain a complete par system. pAV505 and many other pPT23A-like plasmids did not cross-hybridize with the $0.8 \mathrm{~kb} E c o$ RI-KpnI fragment containing IncC (Sesma et ul., 1998), which suggests that this region is poorly conserved in $P$. syringae.

Partial sequencing around oriV-pPT23A disclosed the presence of a putative operon involved in UV resistance, termed $r u l A B$ (Sundin et al., 1996), located immediately after ORF-Pto (Fig. 1a). Since rulAB genes are present in many pPT23A-like plasmids (Sundin \& Bender, 1996; Sesma et al., 1998), it is possible that genes for UV resistance could contribute to the fitness of this plasmid family, and perhaps favour the accumulation of several of its members in a given cell.

Wood et al. (1994) described a gene library cosmid, pPPY 40, and showed that an avirulence phenotype, which matched a resistance gene in pea, required two regions, I and II, as shown by subcloning and transposon mutagenesis. Subsequently, it was shown that cosmids with Tn3Gus insertions in region II were very unstable in P. syringae pv. pisi, with only $1-2 \%$ of cells retaining the cosmid; this contrasted with $95 \%$ stability over a $7 \mathrm{~d}$ period for cells carrying pPPY 40 and $30 \%$ stability for the parent cosmid, pLAFR3 (M. J. Gibbon \& A. Vivian, unpublished). This suggested that region II was involved in the stable maintenance of pPPY40 in P. syringae pv. pisi and probably accounts for its apparent involvement in the avirulence phenotype.

\section{ACKNOWLEDGEMENTS}

The first and second authors contributed equally to this work.

We gratefully acknowledge the award for a cooperative project between Spain and Great Britain by The British 
Council/Ministerio de Educación y Ciencia (Acciones Integradas 1995/96, ref. 279B), which greatly facilitated this investigation. This work was supported with grants BIO940442, from Comisión Interministerial de Ciencia y Tecnología, Spain, and OF 16/1993, from Gobierno de Navarra, Spain, to J.M., and with grants from BBSRC, UK, to A.V.

We gratefully acknowledge the use of the SEQNET facility at BBSRC Daresbury, UK. We are indebted to Noel Keen for his support, which was essential for the initiation of this work.

\section{REFERENCES}

Ankri, S., Bouvier, I., Reyes, O., Predali, F. \& Leblon, G. (1996). A Brevibacterium linens pRBL1 replicon functional in Corynebacterium glutamicum. Plasmid 36, 36-41.

Austin, S. \& Nordström, K. (1990). Partition-mediated incompatibility of bacterial plasmids. Cell 60, 351-354.

Bender, C. \& Cooksey, D. (1986). Indigenous plasmids in Pseudomonas syringae pv. tomato: conjugative transfer and role in copper resistance. J Bacteriol 165, 534-541.

Bender, C. L., Stone, H. E., Sims, J. J. \& Cooksey, D. A. (1987). Reduced pathogen fitness of Pseudomonas syringae pv. tomato Tn5 mutants defective in coronatine production. Physiol Mol Plant Pathol 30, 273-283.

Bender, C. L., Malvick, D. K. \& Mitchell, R. E. (1989). Plasmidmediated production of the phytotoxin coronatine in Pseudomonas syringae pv. tomato. J Bacteriol 171, 807-812.

Bonas, U., Stall, R. E. \& Staskawicz, B. J. (1989). Genetic and structural characterization of the avirulence gene avrBs3 from Xanthomonas campestris pv. vesicatoria. Mol Gen Genet 218, $127-136$.

Comai, L. \& Kosuge, T. (1980). Involvement of plasmid deoxyribonucleic acid in indoleacetic acid synthesis in Pseudomonas savastanoi. J Bacteriol 143, 950-957.

Cooksey, D. A. (1990). Genetics of bactericide resistance in plant pathogenic bacteria. Annu Rev Phytopathol 28, 201-219.

Coplin, D. L. (1989). Plasmids and their role in the evolution of plant pathogenic bacteria. Annu Rev Phytopathol 27, 187-212.

Crouse, G. F., Frischauf, A. \& Lehrach, H. (1983). An integrated and simplified approach for cloning into plasmids and singlestranded phages. Methods Enzymol 101, 78-89.

Curiale, M. S. \& Mills, D. (1983). Molecular relatedness among cryptic plasmids in Pseudomonas syringae pv. glycinea. Phytopathology 73, 1440-1444.

Dangl, J., Ritter, C., Gibbon, M. J., Mur, L. A. J., Wood, J. R., Goss, G., Mansfield, J., Taylor, J. D. \& Vivian, A. (1992). Functional homologs of the Arabidopsis RPM1 disease resistance gene in bean and pea. Plant Cell 4, 1359-1369.

De Mot, R., Nagy, I., De Schrijver, A., Pattanapipitpaisal, P., Schoofs, G. \& Vanderleyden, J. (1997). Structural analysis of the $6 \mathrm{~kb}$ cryptic plasmid pFAJ2600 from Rhodococcus erythropolis NI86/21 and construction of Escherichia coli-Rhodococcus shuttle vectors. Microbiology 143, 3137-3147.

Devereux, J., Haeberli, P. \& Smithies, O. (1984). A comprehensive set of sequence analysis programs for the VAX. Nucleic Acids Res 12, 387-395.

English, R. S., Lorbach, S. C., Huffman, K. M. \& Shively, J. M. (1995). Isolation and characterization of the replicon of a Thiobacillus intermedius plasmid. Plasmid 33, 1-6.

Gallagher, S. R. (1992). Quantitation of GUS activity by fluorometry. In GUS Protocols, pp. 47-59. Edited by S. R. Gallagher. San Diego, CA : Academic Press.
Hidalgo, E., Palacios, J. M., Murillo, J. \& Ruiz-Argüeso, T. (1992). Nucleotide sequence and characterization of four additional genes of the hydrogenase structural operon from Rhizobium leguminosarum bv. viciae. J Bacteriol 174, 4130-4139.

Hiraga, S., Sugiyama, T. \& Itoh, T. (1994). Comparative analysis of the replicon regions of eleven ColE2-related plasmids. J Bacteriol 176, 7233-7243.

Holt, J. G., Krieg, N. R., Sneath, P. H. A., Staley, J. T. \& Williams, S. T. (1994). Bergey's Manual of Determinative Bacteriology, 9th edn. Baltimore: Williams \& Wilkins.

Jackson, R. (1997). Plasmids and virulence in Pseudomonas syringae $p v$. phaseolicola. $\mathrm{PhD}$ thesis, University of the West of England.

Jobling, M. G. \& Holmes, R. K. (1990). Construction of vectors with the p15a replicon, kanamycin resistance, inducible lac $\mathrm{Z} \alpha$ and pUC18 or pUC19 multiple cloning sites. Nucleic Acids Res 18, 5315-5316.

Kamiunten, H. (1995). Involvement of a plasmid in the expression of virulence of Pseudomonas syringae pv. eriobotryae. Ann Phytopathol Soc Jpn 61, 376-380.

Keen, N. T., Tamaki, S., Kobayashi, D. \& Trollinger, D. (1988). Improved broad-host-range plasmids for DNA cloning in Gramnegative bacteria. Gene 70, 191-197.

Keen, N. T., Shen, H. \& Cooksey, D. A. (1992). Introduction of DNA into plant pathogenic bacteria. In Molecular Plant Pathology. A Practical Approach, pp. 45-50. Edited by S. J. Gurr, M. J. McPherson \& D. J. Bowles. Oxford: IRL Press.

King, E. O., Ward, N. K. \& Raney, D. E. (1954). Two simple media for the demonstration of pyocyanin and fluorescein. J Lab Clin Med 44, 301-307.

Kobayashi, D. Y., Tamaki, S. J. \& Keen, N. T. (1990). Molecular characterization of avirulence gene D from Pseudomonas syringae pv. tomato. Mol Plant-Microbe Interact 3, 94-102.

Korch, C., Hagblom, P., Ohman, H., Goransson, M. \& Normark, S. (1985). Cryptic plasmid of Neisseria gonorrhoeae: complete nucleotide sequence and genetic organization. J Bacteriol 163, 430-438.

Mukhopadhyay, P., Mukhopadhyay, M. \& Mills, D. (1990). Construction of a stable shuttle vector for high-frequency transformation in Pseudomonas syringae pv. syringae. J Bacteriol $172,477-480$.

Murillo, J. \& Keen, N. T. (1994). Two native plasmids of Pseudomonas syringae pathovar tomato strain PT23 share a large amount of repeated DNA, including replication sequences. Mol Microbiol 12, 941-950.

Murillo, J., Shen, H., Gerhold, D., Sharma, A. K., Cooksey, D. A. \& Keen, N. T. (1994). Characterization of pPT23B, the plasmid involved in syringolide production by Pseudomonas syringae pv. tomato. Plasmid 31, 275-287.

Nagahama, K., Yoshino, K., Matsuoka, M., Sato, M., Tanase, S., Ogawa, T. \& Fukuda, H. (1994). Ethylene production by strains of the plant-pathogenic bacterium Pseudomonas syringae depends upon the presence of indigenous plasmids carrying homologous genes for the ethylene-forming enzyme. Microbiology 140, 2309-2313.

Nieto, C., Giraldo, R., Fernández-Tresguerres, E. \& Díaz, R. (1992). Genetic and functional analysis of the basic replicon of pPS10, a plasmid specific for Pseudomonas isolated from Pseudomonas syringae pathovar savastanoi. J Mol Biol 223, 415-426.

Nordström, K. (1993). Plasmid replication and maintenance. In Plasmids: a Practical Approach, pp. 1-38. Edited by K. G. Hardy. New York: Oxford University Press. 
Nordström, K. \& Austin, S. J. (1989). Mechanisms that contribute to the stable segregation of plasmids. Annu Rev Genet 23, 37-69. Novick, R. P. (1987). Plasmid incompatibility. Microbiol Rev 51, 381-395.

Page, R. D. M. (1996). TREEVIEW: an application to display phylogenetic trees on personal computers. Comput Appl Biosci 12, 357-358.

Palleroni, N. J. (1984). Genus I. Pseudomonas. In Bergey's Manual of Systematic Bacteriology, vol. 1, pp. 141-199. Edited by N. R. Krieg \& J. G. Holt. Baltimore: Williams \& Wilkins.

Rauzier, J., Moniz-Pereira, J. \& Gicquel-Sanzey, B. (1988). Complete nucleotide sequence of pAL5000, a plasmid from Mycobacterium fortuitum. Gene 71, 315-321.

Rina, M., Caufrier, F., Markaki, M., Mavromatis, K., Kokkinidis, M. \& Bouriotis, V. (1997). Cloning and characterization of the gene encoding PspPI methyltransferase from the antarctic psychrophile Psychrobacter sp. strain TA137. Predicted interactions with DNA and organization of the variable region. Gene 197, 353-360.

Rossi, M., Brigidi, P., Gonzalez Vara y Rodriguez, A. \& Matteuzzi, D. (1996). Characterization of the plasmid pMB1 from Bifidobacterium longum and its use for shuttle vector construction. Res Microbiol 147, 133-143.

Sambrook, J., Fritsch, E. F. \& Maniatis, T. (1989). Molecular Cloning: a Laboratory Manual, 2nd edn. Cold Spring Harbor, NY: Cold Spring Harbor Laboratory.

Sesma, A., Ortiz, A., Bacáicoa, B., Etuláin, D., Aizpún, M. T., Canal, A. \& Murillo, J. (1997). Analysis of plasmid determined phenotypes in Pseudomonas syringae: evidence for plasmid involvement in virulence in P. s. pv. tomato strain PT23. In 10th Congress of the Mediterranean Phytopathological Union, pp. 475-480. Montpellier, France: Société Française de Phytopathologie.

Sesma, A., Sundin, G. \& Murillo, J. (1998). Closely related replicons coexisting in the phytopathogen Pseudomonas syringae show a mosaic organization of the replication region and an altered incompatibility behavior. Appl Environ Microbiol 64, 3948-3953.

del Solar, G., Giraldo, R., Ruiz-Echevarría, M. J., Espinosa, M. \& Díaz-Orejas, R. (1998). Replication and control of circular bacterial plasmids. Microbiol Mol Biol Rev 62, 434-464.
Stachel, S. E., An, G., Flores, C. W. \& Nester, E. W. (1985). A $\operatorname{Tn} 3$ lac $Z$ transposon for the random generation of $\beta$-galactosidase gene fusions: application to the analysis of gene expression in Agrobacterium. EMBO J 4, 891-898.

Studier, F. W. \& Moffatt, B. A. (1986). Use of bacteriophage T7 RNA polymerase to direct selective high-level expression of cloned genes. J Mol Biol 189, 113-130.

Sundin, G. W. \& Bender, C. L. (1993). Ecological and genetic analysis of copper and streptomycin resistance in Pseudomonas syringae pv. syringae. Appl Environ Microbiol 59, 1018-1024.

Sundin, G. W. \& Bender, C. L. (1996). Molecular analysis of closely related copper- and streptomycin-resistance plasmids in Pseudomonas syringae pv. syringae. Plasmid 35, 98-107.

Sundin, G. W., Demezas, D. H. \& Bender, C. L. (1994). Genetic and plasmid diversity within natural populations of Pseudomonas syringae with various exposures to copper and streptomycin bactericides. Appl Environ Microbiol 60, 4421-4431.

Sundin, G. W., Kidambi, S. P., Ullrich, M. \& Bender, C. L. (1996). Resistance to ultraviolet light in Pseudomonas syringae: sequence and functional analysis of the plasmid-encoded $r u l A B$ genes. Gene 177, 77-81.

Vivian, A. \& Gibbon, M. J. (1997). Avirulence genes in plantpathogenic bacteria: signals or weapons? Microbiology 143, 693-704.

West, S. E. H., Schweizer, H. P., Dall, C., Sample, A. K. \& RunyenJanecky, L. J. (1994). Construction of improved EscherichiaPseudomonas shuttle vectors derived from pUC18/19 and sequence of the region required for their replication in Pseudomonas aeruginosa. Gene 128, 81-86.

Wood, J. R., Vivian, A., Jenner, C., Mansfield, J. W. \& Taylor, J. D. (1994). Detection of a gene in pea controlling non-host resistance to Pseudomonas syringae pv. phaseolicola. Mol Plant-Microbe Interact 7, 534-537.

Zhou, C., Yang, Y. \& Jong, A. Y. (1990). Miniprep in ten minutes. Biotechniques 8, 172-173.

Received 20 July 1998; revised 9 October 1998; accepted 12 October 1998. 